\title{
Osteosarcopenia and Liver Transplantation: More than Sarcopenia and Osteopenia Alone
}

\author{
Vildan Binay Safer ${ }^{1}$, Cem Haymana ${ }^{2}$ and Umut Safer*3 \\ ${ }^{1}$ Department of Physical Medicine and Rehabilitation, Sultan Abdul hamid Han Training and Research Hospital, Turkey \\ ${ }^{2}$ Department of Internal Medicine, Gulhane Training and Research Hospital, Turkey \\ ${ }^{3}$ Department of Paliative Care, Sultan Abdulhamid Han Training and Research Hospital, Turkey
}

Received: March 26, 2018; Published: April 12, 2018

*Corresponding author: Umut Safer, Department of Paliative Care, Sultan Abdulhamid Han Training and Research Hospital, Palyatif bakim Ünitesi Üsküdar, Istanbul, Turkey, Tel: 905062356333; Fax: 902165422010; Email: umut.safer@sbu.edu.tr

Abstract

Liver transplantation (LT) is critical treatment option in end stage liver disease. After LT osteoporosis and sarcopenia were increasingly reported complication. Both conditions were like two side of coins so current study started to focus on osteo-sarcopeni to better understand complications related these two conditions. However, methodology of studies on sarcopeni in LT limited to create perspective for osteosarcopeni. Aim of present review is focusing on the literature on osteoporoses management in LT, determining potential limitations of sarcopenia studies in LT and highlighting link between osteoporosis and saropenia to create further perspective for studies in LT.

Abbreviations: LT: Liver Transplantation; EWGSOP: European Working Group on Sarcopenia in Older People; IEGS: International Working Group on Sarcopenia; HU: Hounsfield Units

\section{Introduction}

Liver Transplantation (LT) is an important treatment option for the end stage liver disease. The quality of life for many patients is good following LT however, a number of long term complications have been described. Osteoporosis, characterized by low bone density and disrupted bone architecture leading to fractures, is the most common complications after LT and also compelling complication of may result in significant morbidity and mortality [1-3]. Since the first introduced by Rosenberg in 1989 [4]. sarcopenia has been increasingly studied in geriatric population for two decides and in last decide, several studies reported potential unfavorable effects in chronic obstructive pulmonary disease, cancer, heart failure, and end-stage kidney and LT. Lack of widely accepted definition of sarcopenai for use in research and clinical practice emerged consensus report.

First consensus report was proposed by European Working Group on Sarcopenia in Older People (EWGSOP) in [5]. After, consensus reports of the International Working Group on Sarcopenia (IWGS) [6]. Society on Sarcopenia, Cecelia and Wasting Disorders Trials' Workshop [7]. Were published in 2011 and the Asian working group for sarcopenia were published in 2014 [8]. All these consensus reports highlighted importance of muscle function determination beside muscle mass measurement for sarcopenia, then after definition of sarcopenia were proposed as reduction in muscle function (muscle performance or power) and muscle mass. Although, often appreciated by clinicians in LT, sarcopenia is rarely formally diagnosed.

In these studies prevalence of sarcopenia was referred between 25 and 40, in respect to methodology to determine muscle mass [9]. Despite the non-liner relationship between muscle mass and function, most studies on sarcopenia in LT solely focused on muscle mass assessment for defining sarcopenia. However, validity and reproducibility of these muscle mass measurement results are limited in respect to muscle measurement modalities. Aim of present review is focusing on the literature on osteoporoses management in LT, determining potential limitations of sarcopenia studies in LT and highlighting link between osteoporosis and saropenia to create further perspective for studies in LT.

\section{LT and Osteoporosis}

Following transplantation bone mass is rapidly lost during the postoperative months. The progression of bone lose is prominent in the first six months and usually occurred in spine and the proximal femur $[10,11]$. Fracture risk is also highest in the first six months and most fractures occurred at the site of trabecular bone, with the spine and ribs are the most common sites [12]. Prevalence of osteoporosis in end stage liver disease varies between 12 and 
55 [13]. While in studies on liver transplant survivor range from 25 to $50[14,15]$. Haagsma et al showed that vertebral fracture was developed in $\% 38$ of a cohort of 36 patients undergoing LT in the first six months of post-transplantation stage [16]. Several studies also reported fracture rates around \%25-35 mainly in the first six months after transplantation [17-19].the recent years, osteoporotic fracture rates were decreased following LT. The main reason of this decrease was the reductions in the dose and duration of glucocorticoid treatment. In addition, performing LT at earlier stages of liver disease may be an important factor for the decreased rates of fracture.

\section{Pathogenesis of Osteoporosis Associated With LT}

There are a number of risk factors contribute to osteoporosis and fracture risk following LT. These factors include the using of glucocorticoids and other immunosuppressive drugs, preexisting bone disease, previous fractures, malnutrion, secondary hyperparathyroidism, vitamin D deficiency and hypogonadism [1]. Glucocorticoids have adverse effects on bone metabolism. The main effects of glucocorticoids on the bone metabolism are to suppress bone formation and to increase the bone desorption at early stages of treatment. Glucocorticoids also lead to bone loses via indirect effect such as hypogonadism, reduced intestinal calcium absorption and increased renal calcium excretion. Glucocorticoids associated bone loss is prominent in the first few months of therapy and returns to near baseline values after cessation of treatment. Preexisting low bone mineral density at the time of LT and history of previous fractures have been shown to an important determinant of osteoporosis and fracture risk in the post-transplantation stage $[20,21]$.

In this regard, the type of liver disease is very important. Certain liver diseases such as primary biliary cirrhosis, primary sclerosing cholangitis and alcoholic cirrhosis which have increased risk of osteoporosis are associated with accelerated bone loss and fracture risk after LT. In several studies, increased secretion of parathyroid hormone have been reported in the first few months of transplantation [22,23]. Parathyroid hormone increase bone turnover and reduce bone mass particularly in cortical bone. However, the role of PTH hyper secretion in the pathogenesis of post-transplantation bone loses is not clear. Vitamin D insufficiency is commonly associated with chronic liver disease [24,25]. Vitamin D insufficiency lead to secondary hyperparathyroidism and bone lose and thus may contribute to emerging of osteoporosis following LT [26]. It has been showed that 25-hydroxyvitamin D levels which are an indicator of vitamin D status have a tendency to increase with time in the post-transplantation stage [27]. In addition, hypogonadism which is often associated with chronic liver disease may affect the bone lose after LT.

\section{Prevention and Management of Post-Transplantation Osteoporosis \\ Pre-Transplantation Measures}

Considering the high prevalence of bone metabolism disorders in patients with end stage liver disease, all candidates for LT should be evaluated and treated before the transplantation in terms of osteoporosis and fracture risk. Bone mineral density and parameters of bone and mineral metabolism disease should be performed to all patients before the transplantation. Life style factors which have adverse effects on the bone metabolism such as smoking, alcohol abuse and immobilization should be improved in the pre-transplant stages. All patients should be encouraged for the adequate levels of dietary calcium intake. Weight control and good nutrition should be provided. Also the factors such as hypogonadism, vitamin D insufficiency and secondary hyperparathyroidism should be corrected. $1500 \mathrm{mg}$ of elemental calcium and $800 \mathrm{IU}$ of vitamin D daily are recommended for all patients. The use of medications which have negative effect on the bone metabolism should also be evaluated and minimized to possible dosages.

\section{Management of Post-Transplantation Osteoporosis}

As the rates of osteoporosis and fracture risk are highest in the first months of post-transplant stages, preventive and therapeutic measures should be performed immediately after transplantation without delay. The doses of immunosuppressive drugs especially the glucocorticoids should be minimized to possible dosages. Bisphosphonates are the main drugs of the osteoporosis treatment and act by inhibiting osteoclast-mediated bone resorption and could have beneficial effect on the increased bone turnover which is seen in the first few months after LT. However, there are conflicting results about the efficacy of bisphosphonates in preventing bone lose and fracture risk after LT. Several studies reported a beneficial effect $[28,29]$. However other few studies reported limited or no effect of bisphosphonates use [30,31]. In preventing bone lose and fracture risk.

In a meta-analysis of Kasturi et al., it was showed that bisphosphonates therapy reduced the accelerated bone loss and improved bone mineral density in the first year of transplantation [32]. In this meta-analysis, there was a significant increased mean bone mineral density of $0.03 \mathrm{~g} / \mathrm{cm} 2$ in bisphosphonates group according to the control group at the lumbar spine one year after LT. However, at the femoral neck there was no significant bone mineral density increase. Additionally, in several studies, alendronate [33]. Pamidronate [34] and zolendronic acid [35] were found to be effective in preventing bone lose. Teriparatide also is an effective drug for the treatment of osteoporosis however; there is no study which shows the effect of this drug on the bone loss after LT.

\section{Evaluation of Sarcopenia in LT Trials}

The tool that is currently considered the gold standard method of body composition which are the 4-compartment (4-C) model, magnetic resonance imaging and total body computed tomography scans have not been used to measure muscle mass in these trials. In the sarcopenia assessment for patients undergoing LDLT, several studies used single slice CT analysis in abdominal CT images [3645]. While one studies used a direct segmental multifrequency bioelectrical impedance analysis (BIA) [46]. To determine muscle mass (Table 1), In sarcopenia trials based on single slice CT analysis of muscle mass area, one study reported dorsal muscle group area 
at the twelve thoracic vertebral level, one study reported psoas muscle area at the umbilical level, two study reported the total skeletal muscle area at the level of the third lumbar vertebral level, one study reported the total skeletal muscle of all muscle at the level of the fourth lumbar vertebral level, psoas muscle area at the level of third lumbar vertebral and three study reported three studies reported psoas muscle area at the level of fourth lumbar vertebral, respectively (Table 1).
Heterogeneity in these trials limited to generation of the results for all for patients undergoing LT. Moreover, in these trials, classification of sarcopenia was based on muscle mass measurement, not also on muscle function. All these trials were in retrospective design, except study by Tsien et al. [41]. Which was prospectively measured muscle mass in pre-transplant and posttransplant period? Also, no trials have reported multicenter study results. Muscle mass area measurement by single slice CT analysis

Table 1: Evaluation of studies on sarcopeni in liver transplantation.

\begin{tabular}{|c|c|c|c|c|c|}
\hline Study & Study Design & Participants [n] & $\begin{array}{c}\text { Method for Definition } \\
\text { of Sarcopenia }\end{array}$ & $\begin{array}{c}\text { Muscle Mass } \\
\text { Measurement Area }\end{array}$ & $\begin{array}{l}\text { Impact of sarcopenia } \\
\text { on clinical outcome }\end{array}$ \\
\hline Krell et al. [36] & $\begin{array}{l}\text { Retrospective analysis } \\
\text { of The University } \\
\text { of Michigan Health } \\
\text { System [UMHS] } \\
\text { between June } 2002 \\
\text { and August } 2008\end{array}$ & 207 & $\begin{array}{l}\text { Pre-transplant Single } \\
\text { slice CT analysis }\end{array}$ & $\begin{array}{l}\text { both psoas muscles at } \\
\text { the level of the fourth } \\
\text { lumbar vertebra }\end{array}$ & $\begin{array}{l}\text { increased risk for post } \\
\text { transplants infection } \\
\text { complication and } \\
\text { mortality }\end{array}$ \\
\hline Lee et al. [37] & $\begin{array}{l}\text { retrospective analysis } \\
\text { of the patients who } \\
\text { underwent liver } \\
\text { transplantation at the } \\
\text { University of Michigan } \\
\text { Transplant Center } \\
\text { between } 2000 \text { and } \\
2011\end{array}$ & 325 & $\begin{array}{l}\text { Pre-transplant Single } \\
\text { slice CT analysis }\end{array}$ & $\begin{array}{l}\text { the dorsal muscle } \\
\text { group at the twenve } \\
\text { thoracal vertebral } \\
\text { level and both psoas } \\
\text { muscles at the level } \\
\text { of the fourth lumbar } \\
\text { vertebra }\end{array}$ & $\begin{array}{l}\text { increased risk for post } \\
\text { transplant one-year } \\
\text { mortality, five year } \\
\text { mortality and one-year } \\
\text { complications }\end{array}$ \\
\hline Hamaguchi et al. [38] & $\begin{array}{l}\text { retrospective analysis } \\
\text { of the patients who } \\
\text { underwent LDLT } \\
\text { at Kyoto University } \\
\text { Hospital between } \\
\text { January } 2008 \text { and } \\
\text { October } 2013\end{array}$ & 200 & $\begin{array}{l}\text { Pre-transplant Single } \\
\text { slice CT analysis }\end{array}$ & $\begin{array}{l}\text { The cross-sectional } \\
\text { areas of the right and } \\
\text { left psoas muscles at } \\
\text { the umbilical level }\end{array}$ & $\begin{array}{l}\text { increased risk factors } \\
\text { for mortality }\end{array}$ \\
\hline Bergerson et al. [39] & $\begin{array}{l}\text { retrospective analysis } \\
\text { of the patients who } \\
\text { underwent LDLT } \\
\text { at the University of } \\
\text { Pittsburgh between } \\
2000 \text { to } 2012\end{array}$ & 40 & $\begin{array}{l}\text { pre- and post- } \\
\text { transplant Single slice } \\
\text { CT analysis }\end{array}$ & $\begin{array}{l}\text { skeletal muscle area } \\
\text { at the midpoint of the } \\
\text { third lumbar vertebra }\end{array}$ & $\begin{array}{c}\text { after liver } \\
\text { transplantation } \\
\text { sarcopenia does } \\
\text { not progress but } \\
\text { is arrested and } \\
\text { frequently improves } \\
\text { in the absence } \\
\text { of confounding } \\
\text { conditions }\end{array}$ \\
\hline Englesbe et al. [40] & $\begin{array}{l}\text { retrospective analysis } \\
\text { of the patients who } \\
\text { underwent LDLT at } \\
\text { the Michigan Medical } \\
\text { Center between June } \\
2002 \text { and July } 2008\end{array}$ & 163 & $\begin{array}{l}\text { pre-transplant Single } \\
\text { slice CT analysis }\end{array}$ & $\begin{array}{l}\text { Cross-sectional areas } \\
\text { of the left and right } \\
\text { psoas muscles at the } \\
\text { level of the fourth } \\
\text { lumbar Vertebra }\end{array}$ & $\begin{array}{l}\text { increased risk factors } \\
\text { for mortality }\end{array}$ \\
\hline Tsien et al. [41] & $\begin{array}{l}\text { retrospective analysis } \\
\text { of the patients who } \\
\text { underwent LDLT at the } \\
\text { Cleveland Clinic from } \\
\text { July } 2009 \text { to July } 2011\end{array}$ & 53 & $\begin{array}{l}\text { Pre- and post- } \\
\text { transplant Single slice } \\
\text { CT analysis }\end{array}$ & $\begin{array}{l}\text { cross-sectional areas } \\
\text { of the skeletal muscle } \\
\text { area at the level of the } \\
\text { fourth lumbar Vertebra }\end{array}$ & $\begin{array}{c}\text { non significant, } \\
\text { increased mortality } \\
\text { in patients with } \\
\text { continued reduction in } \\
\text { muscle area }\end{array}$ \\
\hline Thosima et al. [42] & $\begin{array}{l}\text { retrospective analysis } \\
\text { of the patients who } \\
\text { underwent LDLT at } \\
\text { the Kyushu University } \\
\text { Hospital between } \\
\text { November } 2003 \text { and } \\
\text { December } 2011\end{array}$ & 66 & $\begin{array}{l}\text { Pre- transplant Single } \\
\text { slice CT analysis }\end{array}$ & $\begin{array}{l}\text { the psoas muscle at the } \\
\text { caudal end of the third } \\
\text { lumbar vertebra }\end{array}$ & $\begin{array}{c}\text { plasma glutamine } \\
\text { levels after LDLT were } \\
\text { significantly decreased } \\
\text { compared with before } \\
\text { LDLT in patients both } \\
\text { with and without } \\
\text { postoperative early } \\
\text { nutrition }\end{array}$ \\
\hline
\end{tabular}




\begin{tabular}{|c|c|c|c|c|c|}
\hline Valero et al. [43] & $\begin{array}{l}\text { retrospective analysis } \\
\text { of the patients who } \\
\text { underwent LDLT at } \\
\text { the Johns Hopkins } \\
\text { Hospital Between } \\
2000 \text { and } 2013\end{array}$ & 96 & & $\begin{array}{l}\text { The psoas was } \\
\text { measured at the level } \\
\text { of the third lumbar on } \\
\text { the first slice where } \\
\text { both iliac crests were } \\
\text { visible }\end{array}$ & $\begin{array}{l}\text { Increased risk for } \\
\text { complication }\end{array}$ \\
\hline Masuda et al. [44] & $\begin{array}{l}\text { retrospective analysis } \\
\text { of the patients who } \\
\text { underwent LDLT at } \\
\text { the Kyushu University } \\
\text { Hospital between } \\
\text { November } 2003 \text { and } \\
\text { December } 2011\end{array}$ & 202 & $\begin{array}{l}\text { Pre- transplant Single } \\
\text { slice CT analysis }\end{array}$ & $\begin{array}{l}\text { the psoas muscle at the } \\
\text { caudal end of the third } \\
\text { lumbar vertebra }\end{array}$ & $\begin{array}{l}\text { Increased risk for } \\
\text { mortality and sepsis }\end{array}$ \\
\hline $\begin{array}{c}\text { Montano-Loza et al. } \\
{[46]}\end{array}$ & $\begin{array}{l}\text { retrospective analysis } \\
\text { of the patients who } \\
\text { underwent LDLT at the } \\
\text { University of Alberta } \\
\text { Hospital [Edmonton, } \\
\text { Canada] between } 2000 \\
\text { and } 2012\end{array}$ & 248 & $\begin{array}{l}\text { Pre- transplant Single } \\
\text { slice CT analysis }\end{array}$ & $\begin{array}{l}\text { skeletal muscle area } \\
\text { at the third lumbar } \\
\text { vertebra }\end{array}$ & $\begin{array}{l}\text { Increased risk for } \\
\text { longer hospital } \\
\text { stays and a higher } \\
\text { perioperative bacterial } \\
\text { infections, but not } \\
\text { related with mortality }\end{array}$ \\
\hline Kaido et al. [66] & $\begin{array}{l}\text { Retrospective analysis } \\
\text { of the patients who } \\
\text { underwent LDLT } \\
\text { at Kyoto University } \\
\text { Hospital between } \\
\text { February } 2008 \text { and } \\
\text { April } 2012 .\end{array}$ & 124 & $\begin{array}{c}\text { Pre-transplant } \\
\text { Bioelectrical } \\
\text { impedance analysis }\end{array}$ & Total Skeletal muscle & $\begin{array}{l}\text { increased risk factors } \\
\text { for mortality }\end{array}$ \\
\hline
\end{tabular}

based attenuation characteristics of different tissues which are related with density and chemical composition. CT images are comprised of 3-dimensional arrays of voxels, which is assigned an x-ray attenuation value, called Hounsfield units (HU). HU are represented on the Hounsfield scale is a quantitative scale for describing radio density and used in the application of computed axial tomography.

It reflects the linear transformation of the attenuation coefficient measurement in which the radio density of distilled water at standard pressure and temperature (STP) is defined as zero Hounsfield units (HU) and the radio density of air STP is defined as $-1000 \mathrm{HU}$. HU values range from -29 to +150 for skeletal muscle and -190 to -30 for adipose tissue $[46,47]$. However, the chosen fixed range of attenuation values (-190 to -30 Hounsfield units) was relatively wide, such that other structures may have been included within the 'fat' range [48]. Additionally, there is considerable variability in fat attenuation between individual scanners [49]. Which may have been problematic as imaging from multiple hospitals was evaluated. Accuracy of the single-slice CT image analysis was previously assessed by Sheen et al. [50]. Who compared this with the gold standard technique of magnetic resonance imaging.

However, they used the fourth to fifth lumbar region for this analysis and did not report results on specific anatomic landmarks such as the second to third lumbar or third to fourth lumbar regions [51,52]. Moreover, the study by Sheen et al. consisted only of healthy adults, so it was difficult to extrapolate these results for measurements at various levels in patients undergoing LT. In study by Gusto et al. [53]. the quantitative analysis muscle mass area in single slice CT analysis at the axial plane passing through the intersomatic disk between third and fourth lumbar vertebral was compared with appendicle skeletal muscle index, calculated using dual-energy X-ray absorptiometry. In this study, skeletal muscle mass evaluation through CT was only weakly correlated with DXA which is non-gold standard measurement technique for muscle mass measurement and CT measurement of muscle mass were not correlated with hand grip straight which is one of the validate modality for determining muscle function.

The theory body composition analysis of BIA relies on $\mathrm{V}=\mathrm{p} \times \mathrm{I} 2 /$ $\mathrm{R}$ equation where in " $\mathrm{V}$ " is volume, "p" is resistivity, "l" is segment length, " $\mathrm{R}$ " is the segment resistance, and weight, age and sex are incorporated into the estimation by multiple regression [54]. In this content, results of the BIA are linked with the capacity of hydrated tissues to conduct electrical energy which could strongly infused by total body water change. However, ascites and edema which are the cardinal symptoms of cirrhosis or severe liver disease might strongly effect BIA measurements [55].In this content, further studies are warranted before general use of BIA in patients undergoing LDLT.

\section{Link between Osteoporosis and Sarcopenia}

The term "sarco-osteopenia" or "sarcoma-osteoporosis" was first introduced by Binkley and Behring [56]. Individuals presenting with sarco-osteopenia or sarcoosteoporosis would be at higher risk for falls and fractures and, hence, increased morbidity, reduced quality of life, and increased mortality [57]. Although the term has only recently been proposed, the association of muscle and bone mass has been extensively studied [58-62]. Recent studies have found that muscle wasting, established by morphometric analysis, was associated with a preferential type II muscle fiber atrophy, which correlates with bone mineral density and reduced levels 
of Akt, a major regulator of muscle mass [63]. In concordance to this, Khan et la. Showed that lean mass is strongly related to bone mineral status in young adults after LT. this correlations between total body bone mineral density and muscle mass was particularly higher in females ( $\mathrm{r}=0.76, \mathrm{P}=.001)$ than in males ( $\mathrm{r}=0.34, \mathrm{P}=.09$ ) [64]. However, further studies are warranted to define mechanism between osteoporosis and sarcopenia in LT.

\section{Counter measures and future directions}

Low bone mineral density (BMD) usually measured using dual energy X-ray densitometry (DXA) and prior fracture with a BMD measurement 2.5 standard deviations below that of healthy young adults defines the presence of osteoporosis $[65,66]$. DXA is also one of the valid muscle mass measurement technique advised by consensus statements. Further studies in LTDT should focus on muscle mass measurement via DXA for muscle mass measurement and also evaluation of muscle function. This approach gives the possibility to concomitant determination of BMD which will give the advantage of determination of osteo-sarcopeni.

\section{References}

1. Compston JE (2003) Osteoporosis after liver transplantation. Liver Transpl 9(4): 321-30.

2. George J, Ganesh HK, Acharya S, Bandgar TR, Shivane V, et al. (2009) Bone mineral density and disorders of mineral metabolism in chronic liver disease. World J Gastroenterology 15(28): 3516-3522.

3. Mc Donald JA, Dunstan CR, Dilworth P, Sherbon K, Sheil AGR, et al. (1991) Bone loss after liver transplantation. Hepatology 14(4-1): 613-619.

4. Rosenberg I (1989) Summary comments: epidemiological and methodological problems in determining nutritional status of older persons. Am J Clin Nutr 50: 1231-1233.

5. Cruz Jentoft AJ, Baeyens JP, Bauer JM (2010) Sarcopenia: European consensus on definition and diagnosis: report of the European Working Group on Sarcopenia in Older People. Age Ageing 39(4): 412-23.

6. Fielding RA, Vellas B, Evans WJ, Bhasin S, Morley JE, et al. (2011) Sarcopenia: an undiagnosed condition in older adults. Current consensus definition: prevalence, etiology, and consequences. International Working Group on Sarcopenia. J Am Med Dir Assoc 12(4): 249-256.

7. Morley JE, Abbatecola AM, Argiles JM, Baracos V, Bauer J, et al. (2011) Sarcopenia with limited mobility: an international consensus. J Am Med Dir Assoc 12(6): 403-409.

8. Chen LK, Liu LK, Woo J, Assantachai P, Auyeung TW, et al. (2014) Sarcopenia in Asia: consensus report of the Asian working group for sarcopenia. J Am Med Dir Assoc 15(2): 95-101.

9. Montano Loza AJ (2014) Muscle wasting: a nutritional criterion to prioritize patients for liver transplantation. Curr Opin Clin Nutr Metab Care 17(3): 219-225.

10. Monegal A, Navasa M, Guanabens N, Peris P, Pons F, et al. (2001) Martinez de Osaba MJ, et al. Bone disease after liver transplantation: a long-term prospective study of bone mass changes, hormonal status and histomorphometric characteristics. Osteoporos Int 12(6): 484-492.

11. Ebeling PR (2009) Approach to the patient with transplantation-related bone loss. J Clin Endocrinol Metab 94(5): 1483-1490.

12. Haagsma EB, Thijn CJP, Post JG, Slooff MJH, Gips CH (1988) Bone disease after orthotopic liver transplantation. J Hepatol 6(1): 94-100.

13. Ninkovic M, Love SA, Tom B, Alexander GJ, Compston JE (2001) High prevalence of osteoporosis in patients with chronic liver disease prior to liver transplantation. Calcif Tissue Int 69(6): 321-326.

14. Segal E, Baruch Y, Kramsky R, Raz B, Tamir A, et al. (2003) Predominant factors associated with bone loss in liver transplant patients-after prolonged post-transplantation period. Clin Transplant 17(1): 13-19.

15. Giannini S, Nobile M, Dalle Carbonare L, Ciuffreda M, Germoni V, et al. (2007) Vertebral morphometry by X-ray absorptiometry before and after liver transplant: a cross sectional study. Eur J Gastroenterol Hepatol 13(10): 1201-1207.

16. Meys E, Fontanges E, Fourcade N, Thomasson A, Pouyet M, et al. (1994) Bone loss after orthotopic liver transplantation. Am J Med 97(5): 445450 .

17. Navasa M, Monegal A, Guanabens N, Peris P, Rimola A, et al. (1994) Bone fractures in liver transplant patients. Brit J Rheumatol 33(1): 52-55.

18. Hamberg SM, Piers DA, Van den Berg AP, Slooff MJH, Haagsma EB ( 2000) Bone mineral density in the long term after liver transplantation. Osteoporos Int 11(7): 600-606.

19. Guichelaar MMJ, Hay JE, Clarke BE, Malinchoc M (2000) Incidence and pretransplant risk factors for posttransplant fractures in patients with chronic cholestatic liver disease. J Hepatol 31(2): 49.

20. Mc Donald JA, Dunstan CR, Dilworth P, Sherbon K, Sheil AGR, et al. (1991) Bone loss after liver transplantation. Hepatology 14(4-1): 613-619.

21. Arnold JC, Hauser D, Ziegler R, Kommerell B, Otto G, et al. (1992) Bone disease after liver transplantation. Transplant Proc 24: 2709-2710.

22. Floreani A, Fries W, Luisetto G, Burra P, Fagiuoli S, et al. (1998) Bone metabolism in orthotopic liver transplantation: a prospective study. Liver Transplant Surg 4: 311-319.

23. Crosbie OM, Freaney R, Mc Kenna MJ, Hegarty JE (1999) Bone density, vitamin $\mathrm{D}$ status, and disordered bone remodeling in endstage chronic liver disease. Calcif Tissue Int 64(4): 295-300.

24. Monegal A, Navasa M, Guanabens N, Peris P, Pons F, et al. (1997) Osteoporosis and bone mineral metabolism disorders in cirrhotic patients referred for orthotopic liver transplantation.Calcif Tissue Int 60(2): 148-154.

25. Stein EM, Cohen A, Freeby M, Rogers H, Kokolus S, et al. (2009) Severe vitamin D deficiency among heart and liver transplant recipients. Clin Transplant 23(6): 861-865.

26. Floreani A, Mega A, Tizian L, Burra P, Boccagni P, et al. (2001) Bone metabolism and gonad function in male patients undergoing liver transplantation: a two year longitudinal study. Osteoporos Int 12(9): 749-754.

27. Monegal A, Navasa M, Guanabens N, Peris P, Pons F, et al. (2001) Bone disease after liver transplantation: a long-term prospective study of bone mass changes, hormonal status and histomorphometric characteristics. Osteoporos Int 12(6): 484-492.

28. Crawford BA, Kam C, Pavlovic J (2006) Zoledronic acid prevents bone loss after liver transplantation: a randomized, double-blind, placebocontrolled trial. Ann Intern Med 144(4): 239-248.

29. Bodingbauer M, Wekerle T, Pakrah B, Roschger P, Peck Radosavljevic M, et al. (2007) Prophylactic bisphosphonate treatment prevents bone fractures after liver transplantation. Am J Transplant 7(7): 1763-1769.

30. Ninkovic M, Love S, Tom BD, Bearcroft PW, Alexander GJ, et al. (2002) Lack of effect of intravenous pamidronate on fracture incidence and bone mineral density after orthotopic liver transplantation. J Hepatol 37(1): 93-100.

31. Riemens SC, Oostdijk A, van Doormaal JJ, Thijn CJ, Drent G, et al. (1996) Bone loss after liver transplantation is not prevented by cyclical etidronate, calcium and alphacalcidol. The Liver Transplant Group, Groningen. Osteoporos Int 6(3): 213-218. 
32. Kasturi KS, Chennareddygari S, Mummadi RR (2010) Effect of bisphosphonates on bone mineral density in liver transplant patients: a meta-analysis and systematic review of randomized controlled trials. Transpl Int 23(2): 200-207.

33. Atamaz F, Hepguler S, Karasu Z, Kilic M, Tokat Y (2006) The prevention of bone fractures after liver transplantation: experience with alendronate treatment. Transplant Proc 38(5): 1448-1452.

34. Dodidou P, Bruckner T, Hosch S, Haass M, Klar E, et al. (2003) Better late than never? Experience with intravenous pamidronate treatment in patient with low bone mass or fractures following cardiac or liver transplantation. Osteoporos Int 14(1): 82-89.

35. Reeves H, Francis R, Manas D, Hudson M, Day C (1998) Intravenous bisphosphonate prevents symptomatic osteoporotic vertebral collapse in patients after liver transplantation. Liver Transpl Surg 4(5): 404-409.

36. Krell R, Kaul DR, Martin AR, Englesbe MJ, Sonnenday CJ, et al. (2013) Association between sarcopenia and the risk of serious infection among adults undergoing liver transplantation. Liver Transpl. 19(12): 1396402.

37. Lee CS, Cron DC, Terjimanian MN, Canvasser LD, Mazurek AA, et al. (2014) Dorsal muscle group area and surgical outcomes in liver transplantation. Clin Transplant. 28(10): 1092-1098.

38. Hamaguchi Y, Kaido T, Okumura S, Fujimoto Y, Ogawa K, et al. (2014) Impact of quality as well as quantity of skeletal muscle on outcomes after liver transplantation. Liver Transpl. 20(11): 1413-1419.

39. Bergerson JT, Lee JG, Furlan A, Sourianarayanane A, Fetzer DT, et al. (2015) Liver transplantation arrests and reverses muscle wasting. Clin Transplant 29(3): 216-221.

40. Englesbe MJ, Patel SP, He K, Lynch RJ, Schaubel DE, et al. (2010) Sarcopenia and mortality after liver transplantation. J Am Coll Surg 211(2): 271-278

41. Tsien C, Garber A, Narayanan A, Shah SN, Barnes D, et al. (2014) Postliver transplantation sarcopenia in cirrhosis: a prospective evaluation. J Gastroenterol Hepatol 29(6): 1250-1257.

42. Toshima T, Shirabe K, Kurihara T, Itoh S, Harimoto N, et al. (2015) Profile of plasma amino acids values as a predictor of sepsis in patients following living donor liver transplantation: Special reference to sarcopenia and postoperative early nutrition. Hepatol 45(12): 1170-1177.

43. Valero V, Amini N, Spolverato G, Weiss MJ, Hirose K, et al. (2015) Sarcopenia adversely impacts postoperative complications following resection or transplantation in patients with primary liver tumors. J Gastrointest Surg. 19(2): 272-281.

44. Masuda T, Shirabe K, Ikegami T, Harimoto N, Yoshizumi T, et al. (2014) Sarcopenia is a prognostic factor in living donor liver transplantation. Liver Transpl 20(4): 401-407.

45. Montano Loza AJ, Meza Junco J, Baracos VE, Prado CM, Ma M, et al. (2014) Severe muscle depletion predicts postoperative length of stay but is not associated with survival after liver transplantation. Liver Transpl 20 (6): 640-648.

46. Hayashi F, Matsumoto Y, Momoki C, Yuikawa M, Okada G, et al. (2013) Physical inactivity and insufficient dietary intake are associated with the frequency of sarcopenia in patients with compensated viral liver cirrhosis. Hepatol Res 43(12): 1264-1275.

47. Prado CM, Birdsell LA, Baracos VE (2009) The emerging role of computerized tomography in assessing cancer cachexia. Curr Opin Support Palliat Care 3(4): 269-275.

48. Parkin E, Plumb AA, O'Reilly D, Renehan AG Body (2012) composition and outcome in patients undergoing resection of colorectal liver metastases. Br J Surg 99(7): 1021-1022.

49. Yoshizumi T, Nakamura T, Yamane M, Islam AH, Menju M, et al. Radiology (1999) Abdominal fat: standardized technique for measurement at CT.
Radiology 211(1): 283-286.

50. Shen W, Punyanitya M, Wang Z, Gallagher D, St Onge MP, et al. (2004) Total body skeletal muscle and adipose tissue volumes: estimation from a single abdominal cross-sectional image. J Appl Physiol 97(6): 23332338.

51. Safer VB, Safer U (2013) Usefulness and limitations of single-slice computed tomography analysis at the third lumbar region in the assessment of sarcopenia. Crit Care 17(6): 466.

52. Safer U, Binay Safer V (2014) Could single-slice quantitative computerized tomography image analysis at the midpoint of the third lumbar region accurately predict total body skeletal muscle? JPEN J Parenter Enteral Nutrm 38(4): 415.

53. Giusto M, Lattanzi B, Albanese C, Galtieri A, Farcomeni A, et al. (2015) Sarcopenia in liver cirrhosis: the role of computed tomography scan for the assessment of muscle mass compared with dual-energy X-ray absorptiometry and anthropometry. Eur J Gastroenterol Hepatol 27(3): 328-334.

54. Ward LC (2012) Segmental bioelectrical impedance analysis: an update. Curr Opin Clin Nutr Metab Care 15(5): 424-429.

55. Safer U, Tasci I, Binay Safer V, Doruk H (2013) Comment on Impact of sarcopenia on survival in patients undergoing living donor liver transplantation. Am J Transplant 13(9): 2505.

56. Binkley N, Buehring B (2009) Beyond FRAX: it's time to consider "sarcoosteopenia". J Clin Densitom 12(4): 413-416.

57. Binkley N, Buehring B (2009) Beyond FRAX: it's time to consider "sarcoosteopenia". J Clin Densitom12(4): 413-416.

58. Sowers MF, Kshirsagar A, Crutchfield MM, Updike S (1992) Joint influence of fat and lean body composition compartments on femoral bone mineral density in premenopausal women. Am J Epidemiol. 136(3): 257-265.

59. Sowers M, Kshirsagar A, Crutchfield M, Updike S (1991) Body composition, age and femoral bone mass of young adult women. Ann Epidemiol 1(3): 245-254.

60. Burr DB (1997) Muscle strength, bone mass, and age-related bone loss. J Bone Miner 12(10): 1547-1551.

61. Proctor DN, Melton LJ, Khosla S, Crowson CS, O'Connor MK, et al. (2000) Relative influence of physical activity, muscle mass and strength on bone density. Osteoporos Int 11(11): 944-952.

62. Frost HM (1997) On our age-related bone loss: insights from a new paradigm. J Bone Miner Res. 12(10): 1539-1546.

63. Terracciano C, Celi M, Lecce D, Baldi J, Rastelli E, et al. (2013) Differential features of muscle fiber atrophy in osteoporosis and osteoarthritis. Osteoporos Int 24(3): 1095-1100.

64. Khan KM, Mulia S, Kaul R, Raatz S (2007) Effect of nutrition and body composition on bone density after liver transplantation. Transplant Proc 39(10): 3292-3294.

65. (1994) Assessment of fracture risk and its application to screening for postmenopausal osteoporosis.Report of a WHO Study Group. World Health Organ Tech Rep Ser 843: 1-129.

66. Kaido T, Ogawa K, Fujimoto Y, Ogura Y, Hata K, et al. (2013) Impact of sarcopenia on survival in patients undergoing living donor liver transplantation. Am J Transplant 13(6): 1549-1556. 
(C) (i) This work is licensed under Creative

Submission Link: https://biomedres.us/submit-manuscript.php

Assets of Publishing with us
BIOMEDICAL
RESARCHES

